Ivashkevych Ernest

$\mathrm{PhD}$ in Psychology, Professor's assistant of the Department of Practice of English of Rivne State University of the Humanities, the translator https://orcid.org/0000-0001-7219-1086

DOI https://doi.org/10.35619/praprv.v1i16.214

\title{
THE PARADIGM OF DIALOGUE INTERACTION AS A WAY OF THE PROFESSIONAL DEVELOPMENT OF FUTURE TRANSLATOR
}

\begin{abstract}
In the article we've shown that the professional development of the person takes place through qualitative changes that facilitate the emergence of a completely new level of its integrity. The latter involves qualitative changes in the characteristics of the person, the transformation personal characteristics which have already been formed, fairly consistent guidelines, values orientations, motives of behavior under the influence of constantly changing social relations. Also, the professional development of the person is carried out as a result of restructuring its orientation. At the same time, the professional orientation of the person is the result of a contradictory combination of socialization, that is emphasized on the mastery of a person with socially significant experience and culture and provide individualization (the process of the development of intelligence, will, aesthetic taste, creative abilities of the person, etc.). In the process of professional development of the person occurs the formation of the subject's integrity. This integrity consists of: 1) subordination of all elements of the structure of the personality, the subject's orientation, which ensures the continuity, the length of all periods of person's professional development; 2) to acquire the necessary professionally significant qualities, properties and
\end{abstract} characteristics.

We've proved that significant features of the professional formation are found in the process of finding the person's individual ways of performing professional activity, which is accompanied by the formation of individual personally meaningful (including creative experience), professional self-consciousness, a system of professional motives, personal meanings, values and senses. The analysis of scientific researches, which in one way or another one deals with the problem of professional formation, shows the unity of researchers' opinions that professional formation is a dynamic process of transformation (or restructuring) personal and professional qualities, characterized by self-determination, self-improvement, self-education, self-actualization, selfrealization, actually shaping one's consciousness. Thus, professional development can be showed as a long process of mastering the profession.

Thus, the analysis of the scientific literature indicates that the process of professional formation can be represented in two ways: the scheme of procedural reproduction (as a temporary sequence of stages, periods, parts) and the structure of professional activity (as a set of ways and means of performing professional activity, when their compliance is not a temporary determination, but a targeted presentation and realization). Professional formation is also understood as the development of person's professional competence, as a process of mastering the means of solving professional problems and tasks, as well as mastering models of making professionally significant decisions.

We identified the main stages of the professional development of a specialist: a preparatory (pre-university) stage, associated purely with the choice of profession; the initial (university) stage, during which professionally important skills, characteristics and personal traits are formed; the main (postgraduate) stage as a period of the development of personal qualities of the man facilitating his/her full self-realization in the professional activity. At this stage the formation of the professional as a person takes place.

So, we have to admit that the problem of the development of the person of translator is a dynamic process that constantly unfolds in time and space, proceeds from the moments of formation 
of professional intentions to full realization of oneself in the process of creative professional activity, the main contradiction of which is the contradiction between unique personality traits and objective requirements of the leading professional activities the significance of which is that it should be led to further development of the person. It was emphasized that by realizing himself/herself in the leading professional activity, the person gradually changed, which led to the restructuring of the motives of his/her leading activity, to the formation of new properties, qualities and characteristics of the person, which are extremely important for professional activity in general.

Key words: dialogue interaction, professional development, creative professional activity, professional intentions, professional competence, creative experience.

Problem's statement. The professional development of a person is the most important component of the formation of his/her personality. We've to emphasize that the basis of a truly deep understanding of the individual is the study of the process of generation and transformation of professional abilities and skills to perform professional activities carried out in specific social conditions. Also we've to note that the main is what is the process of person's understanding about whom a person was at one age stage of his/her development, and whom he/she will become at the next stage, and it depends on what he/she has done, achieved, including the professional sphere of the person. However, we've to emphasize that this process for future professionals is multifaceted and extremely complex phenomenon, so it is logical that quite a few issues remain unresolved in the psychological literature.

Analysis of recent researches and publications. The term "professional development of the person" has widely been used in psychological and pedagogical literature (Arbuthnott \& Frank, 2000). Contemporary researchers consider the process of the "professional development" of a specialist from different points of view. In foreign researches (Dijkgraaf, Hartsuiker \& Duyck, 2017), as a rule, there are five main psychological concepts of the professional development of the person: differential diagnosis, psychoanalytic, the theory of decision making and explication, typological, the theory of personal and professional development and others.

In Psychology professional development is considered in two contexts: personal development and professional growth. Personal development is a continuous purposeful process of progressive change of the person (Mykhalchuk, \& Ivashkevych, 2019), the formation of relations with the world and the society (Mykhalchuk \& Bihunova, 2019). Professional growth is the formation of the subject of the activity (Mykhalchuk \& Khupavsheva, 2020), the process of gradual resolution of a complex of contradictions between socio-professional requirements for the individual and his/her desires and capabilities (Green, 1998), the formation of professional motivation, competence, professionally important qualities, personality intelligence, etc. (Dubovyk, Mytnyk, Mykhalchuk, Ivashkevych \& Hupavtseva, 2020).

The purpose of the research. In this article we've to analyze the process of professional development of the person in the paradigm of dialogue interaction. We predict that he analysis of psychological and pedagogical researches allows us to establish the most significant features of professional formation which are shown in finding by the teacher the individual ways of performance of his/her professional activity.

The results of the research and their discussion. Analyzing the process of professional development of the person, many researchers identify the stages, levels of professional growth. In such a way, a professional approach to the problems of professional formation involves updating the basic characteristics of the personal-motivational and operational-technical aspects of professional activity. Mastering professional skills involves the development of knowledge, skills and abilities of a specialist, which are formed on the basis of professionally significant abilities, which are mastered at the University (operational side of professional formation). The abilities of the person, which are developed in the process of professional activity, form a complex of professionally important qualities, providing prerequisites for the further personal development of a specialist, achievement of his/her professional skills. Professional ability is one of the most 
important components of a professional development; the last "pushes" a person to choose a certain professional field, further ensuring the successful mastery of a specialist in a future profession.

Understanding the peculiarities of professional formation, as we note, becomes impossible without studying the content and the structure of personal motives, which are the main facilitative power of choosing a profession and the desire to achieve meaningful results in it. The course of the professional development is also directly related to the development of personal consciousness. Adequate knowledge of themselves, their capabilities, abilities, value orientations allow a future specialist to choose the most appropriate way for the structure of his/her personal sphere of the professional activity. Successes or failures achieved in the profession, in turn, correct a person's perception of themselves, affect their self-esteem, the level of aspirations and self-awareness in general.

Professional formation also involves the active inclusion of a person into a new social environment for him/her, characterized by standards of communication, behavior, values, stereotypes, moral rules and imperatives, etc. Interpersonal relationships that are formed in a professional team largely determine the course of the person's professional adaptation, formation of his/her social status. Therefore, the structure of professional formation may include social and psychological characteristics of a person, determining his/her place in a professional group, social status, etc.

The analysis of psychological and pedagogical researches allows us to establish the most significant features of professional formation which are shown in finding by the teacher the individual ways of performance of his/her professional activity.

Thus, describing the process of the professional development of the individual in the paradigm of designing a professional life path, identifies several phases that the individual goes through during this formation: the stage of being optant - the phase of choosing a profession; the adept - a person thinks that his/her profession is a mission, who actively masters it; the adapter the young specialist's habituation to provide the activity, understanding of the many subtleties and features of this professional activity; the intern - a sufficiently experienced employee who is able to perform basic professional functions independently and quite successfully; the master, the authority, the mentor - the highest level of the professionalism of a specialist (Mytnyk, Matvienko, Guraliuk, Mykhalchuk \& Ivashkevych, 2021).

We identified the main stages of the professional development of a specialist: a preparatory (pre-university) stage, associated purely with the choice of profession; the initial (university) stage, during which professionally important skills, characteristics and personal traits are formed; the main (postgraduate) stage as a period of the development of personal qualities of the man facilitating his/her full self-realization in the professional activity. At this stage the formation of the professional as a person takes place.

So, we have to admit that the problem of the development of the person of translator is a dynamic process that constantly unfolds in time and space, proceeds from the moments of formation of professional intentions to full realization of oneself in the process of creative professional activity, the main contradiction of which is the contradiction between unique personality traits and objective requirements of the leading professional activities the significance of which is that it should be led to further development of the person. It was emphasized that by realizing himself/herself in the leading professional activity, the person gradually changed, which led to the restructuring of the motives of his/her leading activity, to the formation of new properties, qualities and characteristics of the person, which are extremely important for professional activity in general.

Therefore, the conceptual model of the professional development of a future translator, in our opinion, will necessarily includes professional readiness to perform the activity. The formation of readiness for foreign language communication and translation becomes a necessary prerequisite for the training of specialists who speak a foreign language and are able to get in touch with representatives of another culture. In psychological researches (Aleksandrov, Memetova \& Stankevich, 2020), the readiness for foreign language communication and translation is considered as an integral personal neoplasm that involves a high level of knowledge of a foreign language, 
linguistics in general, as well as the specialist's possession of gaining the necessary communication skills. We also attribute the state of readiness mainly to intellectual and volitional states, as its leading characteristics are the desire successfully to solve problems of self-development, selfimprovement, creativity and confidence in the development of their professional abilities, which can be considered as a necessary condition for volitional decision-making. management of their behavior and providing actions in order to achieve the goal of their activity. The state of readiness of a future translator for self-development and self-realization, we consider as a desire of the individual to overcome internal contradictions, states of anxiety and cognitive dissonance, creative implementation of plans and programs of self-realization. The readiness of a future translator for self-development is determined by general and special knowledge, skills, mental processes, states and personality traits, and ultimately by the responsibility for the results of self-improvement and personal growth.

It was stated that that conceptual model would necessarily include professional readiness for performing the activity. Willingness is characterized by the different nature of the interconnections of its structural components (a cognitive component - knowledge of a foreign language, a linguistic one - linguistic competence, the component of implementation - communication skills). Considering the readiness of a student as a component of person's intercultural communication as a set of individually significant psychological factors of a specialist, we (taking into account the diagnostic goals) have identified the characteristics of different levels of the development of each of the factors of readiness, which we mean as a criterion basis for studying the phenomenon of students' readiness for organizing the process of successful intercultural communication. The first (a cognitive) component is considered in the context of this study as varying levels of foreign language acquisition. In fact, in our opinion, a cognitive component of readiness contains the linguistic competence of the person, as well as his/her communicative skills and the peculiarities of using them in the process of translation activity.

It is also important to emphasize that the state of readiness for foreign language communication should be attributed to the intellectual and volitional states of the individual, as its leading components are the desire to successfully solve communicative problems, show creativity and confidence in students' communicative skills, which, in turn, can be considered as a characteristic of mental and motor-volitional decision-making process, conscious management of one's own behavior during decision-making and implementation of thoughts. The formation of a state of readiness for foreign language communication means the creation of a system of motives, attitudes, which, having been updated if it is necessary, provides the future translator with the opportunity to effectively perform his/her functions in the process of the professional activity.

Students' readiness to perform the translation activity implied a professional competence of a specialist, such as knowledge of linguistic material, knowledge of ways, techniques and means of actualization of this knowledge in a particular situation, a high level of the development of skills of listening, speaking, writing in a foreign language. The readiness of a specialist to perform translation activities implies his/her ability to exhibit a high level of thinking and cognitive activity, independence and self-organization in solving communicative and cognitive tasks and problems. It was determined that different levels of mastering the system of necessary knowledge, skills, different degrees of the activity and autonomy of the person deals with different degrees of readiness of the translator to make independent prudent decisions and carry out independent actions connected with the activity of the interpreter.

We emphasize that a specialist's readiness for professional activity contains three components: a) motivational readiness; b) meaningful readiness; c) operational readiness. Considering that the professional activity of the translator is characterized by axiological orientation, it is stated that the translator's readiness for professional activity will also contain the fourth component, we call it "valuable readiness".

Taking into account the second (axiological) indicator of students' readiness for intercultural communication, linguistic knowledge, skills and abilities, we also meant that this axiological index should include values orientations, which will characterize to a great extent moral values of the student. For the translator, the axiological indicator of readiness to perform translation 
activities is dominant, because the value orientations of the specialist determine the motivation of the subject's activity, the orientation of his/her interests and aspirations.

The conceptual model of the professional development of a future translator also includes professional competence, which, in turn, includes certain specific competences that provide the translator with the ability to perform professional activities. It should be noted that professional competence is a set of interconnected knowledge, qualities, components of experience, characteristics of personality abilities that are some set in relations to the processes of the professional activity. Also, the professional development of a translator, to our mind, depends to a large extent on the development of a specialist's translation consciousness. The conceptual model of professional formation of a future translator is shown on Fig. 1.

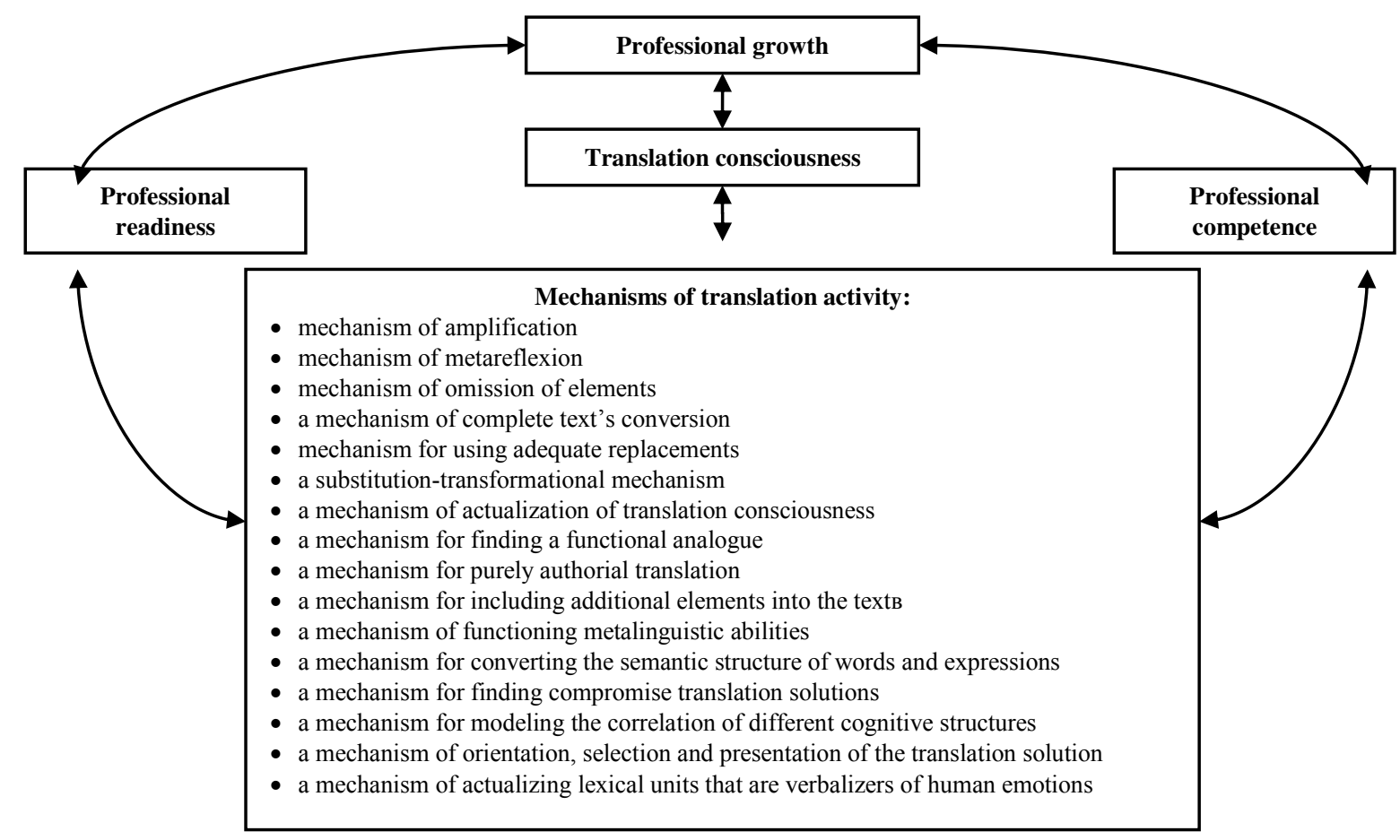

Fig. 1. Conceptual model of professional formation of future translator

One of the main differences between a man and the world of surrounding environment, the distinction that reflects the person's physiological, pedagogical and social development is the presence of a special psychic process, which we call "speech". Speech is a process of communication by people through the language (Crookes, 1989). In order to be able to speak and to understand the speech of others, you need to know the language and be able to use it.

In Psychology it is possible to share the concepts of "a language" and "a speech". The language is a system of conditional symbols which transmit the combination of sounds that have a certain meaning and the special meaning for all people of all over the world. Language is made by a society and it is a form of reflection in the public consciousness of people of their social existence. Each language is formed in the process of communication of people, but at the same time it is a product of socio-historical development. Each carrier of the language becomes a potential source of the development and modernization of the language.

Unlike the language, speech is called the verbal process of communication itself, which can be proceeded in a form of a message, a statement, a question, the order of words, phrases and sentences. From a psychological point of view communication through the language is a less complex phenomenon than speech itself. In order to convey certain information through speech, it is necessary not only to pick up corresponding words that have a certain meaning, but also to specify them. Any word is a some specific form of generalization, so in the speech it should be narrowed down to a certain level or a content. This can be achieved by entering a word into a particular context. In addition to the content that we transmit with verbal meanings, our speech also expresses 
our emotional attitude to what we are talking about. This phenomenon is called the emotional and expressive side of speech, due to the tone of the sound of words, which we use to pronounce the expression we express. Lastly, speech can also have a psychological side, since the speech often contains a meaningful subtext that reflects the purpose (or the motive of speech), which was associated with one or another statement.

Thus, from the psychological point of view communication is a complex and multifaceted process. The present state of speech was preceded by a long process of phylogenetic development of a man. It should be noted that speech is a specific type of human activity. Speech and with it the language appeared for the first time in a human society. The speech in its development has the following psychologically determined stages:

- complex kinetic speech (similar to the speech of animals);

- manual (kinetic) speech (separation of speech movements from actions and their use as the means of communication);

- sounds having been articulated by speech of people (sound speech and thinking separated from direct actions);

- written speech (Booth, MacWhinney \& Harasaki, 2000).

Thus, speech of people is a product of socio-historical development, during which speech began to perform a number of functions and it is occupied as one of the most significant places in the mental and social life of a man. Human speech has a variety of forms. But no matter what form of speech we use, it will relate to one of two main types of speech: oral or written ones. So called «primary form» of speech is speech in the form of conversation. Such speech is called colloquial or dialogical, which is actively supported by the partner of communication. Usually two people take part in the conversation, using the simplest forms of the language and its expressions. As a result, spoken speech in the psychological paradigm is the simplest form of speech. It does not require expanded speech, as the partner of communication in the process of speaking is well aware of what has been being said and can be added to the expression according to the sense of the sentence that another person said. In such cases, one word can replace the whole expression.

The other form is the speech of one person it is while the listeners only perceive the speech of the speaker, but directly do not take part in the process of communication. Such a speech is called monologue. Monologue speech from a psychological point of view is more complex than dialogical. It requires from the speakers the ability to communicate, consistently to express their thoughts. At the same time, he/she (the speaker) has to evaluate how the learners are assimilated with the information that he/she transmits, that is he/she has to follow not only when the speech is spoken in the audience. As it was noted above, dialogical and monologue speech not only have external differences, but also psychological ones. Thus, for example, a monologue can have such an external form as a dialogue, that is the scientists periodically refer to the listeners or to the imaginary opponent. These two types of spoken speech can also be characterized from the point of view of the speaker or the listener. In this case it is accepted to speak about the activity or passivity of speech in general. The active form of speech is the speech of the speaker, in this case the speech of the listener appears in a passive form. The fact is in that when we listen to another person we speak some words about the person himself/herself. At the same time, it does not manifest itself, although the speech activity is present. As well-known psychologists point out, children develop active or passive forms of speech at the same time. The child at first learns to understand the speech of others, and only then he/she begins to speak himself/herself. But even when the people became elder they are differed by the level of the development of active and passive forms of speech. It often happens that a person understands the speech of other people well, but poorly presents his/her thoughts. Conversely, a person can speak well enough, but he/she can not listen to others at all.

A completely different kind of speech is writing. Written language differs from the oral one by the fact that it is depicted graphically, with the help of written signs. Written speech also has psychological differences from oral one. In such a way in oral speech words follow one after another, that is, when one word sounds, the previous one is no longer perceived either by a speaker or by a listener. In writing both the persons who write and the readers who are able to perceive a number of words - both they need it they can return to a few lines or pages back. This creates 
certain benefits of writing over oral speech. Thus, written speech is easier to perceive, on the one hand, and written speech is a more complex form of speech, on the other form. It requires a more thoughtful construction of the expressions, more accurate presentation of ideas, because we are not able to provide an emotional color to written speech. In addition, the process of forming and expressing opinions are not the same things. This is evidenced by that fact that it is easier for one people to convey their opinions in writing, and to others - to present them orally.

Scientists allocate another type of speech - a kinetic one. Psychologists note that such a type of speech has been for people since ancient times. At first it was the basis and, probably, the only type of speech, which is fulfilled all the speech functions. Over the times, this type of speech has lost its functions and today it is used only as emotionally-expressive elements of speech which are gestures. Very often we accompany our speech with gestures, which gives it additional emotional expressiveness. But there are quite large groups of people for whom kinetic speech remains a main form of speech. Here we are talking about people who from their birth or those ones who have lost their ability to speak and to listen. But in this case the kinetic speech is significantly different from the kinetic speech of the ancient man. It is more developed and has integral system of sign signals.

Scientists also consider it appropriate to talk about another two types of speech: internal and external ones. In the opinion of psychologists, internal speech is primarily connected with ensuring the process of thinking with the process of communication, exchange of information. This phenomenon is very complex from a psychological point of view, which provides interconnection both of speech and thinking.

It should also be noted that any type of speech, including oral and written ones, has its purpose, and it performs certain functions. The main functions of speech are utterance, influence, message, designation.

The function of the utterance is that one, when by means of speech a person expresses his/her attitude to a certain subject, a phenomenon to himself/herself. In expressing our attitude to something in speech, it has a certain emotional color, which promotes the understanding of our attitude towards the subject in questions.

The function of influence is that by means of speech we try to induce another person or a group of people to a certain action or to a form the listeners present a certain point of view on something. Typically, this speech function is carried out through an order. This process we call persuasion.

The function of message is characterized by the exchange of thoughts and information between people who are using words. This feature ensures the process of communication between people. During these contacts we organize not only the exchange of information, but also our interaction. We note that it was this function in the historical plan which is the main source of human speech development.

The function of the notation is the ability to name objects and phenomena. Thanks to this function we are able to think abstractly, as well as to exchange information with another person. According to scientists, the implementation of this function became possible only at the highest degree of speech development. Graphically all types of speech can be presented on Figure 2 .

We also highlight the function of prediction that characterizes the person's ability to make assumptions about the subsequent conversation, the communication of two or more people through the mechanism of anticipation. This function, in our opinion, is the most important in terms of mastering a spoken foreign language, because expressions in a non-native language are often impossible to construct in the absence of anti-cycling patterns of personality thinking. In the future we will proceed from this assumption in our presentation of the theoretical material, as well as in the experimental part of the research. In general, a dialogue as a form of speech communication is the communication of two subjects with the help of a language. But from the point of view of the content side, dialogues vary significantly depending on the goals and objectives that the participants seek to achieve from the language load (the choice of the vocabulary, a style, a language, etc.) and other factors. 

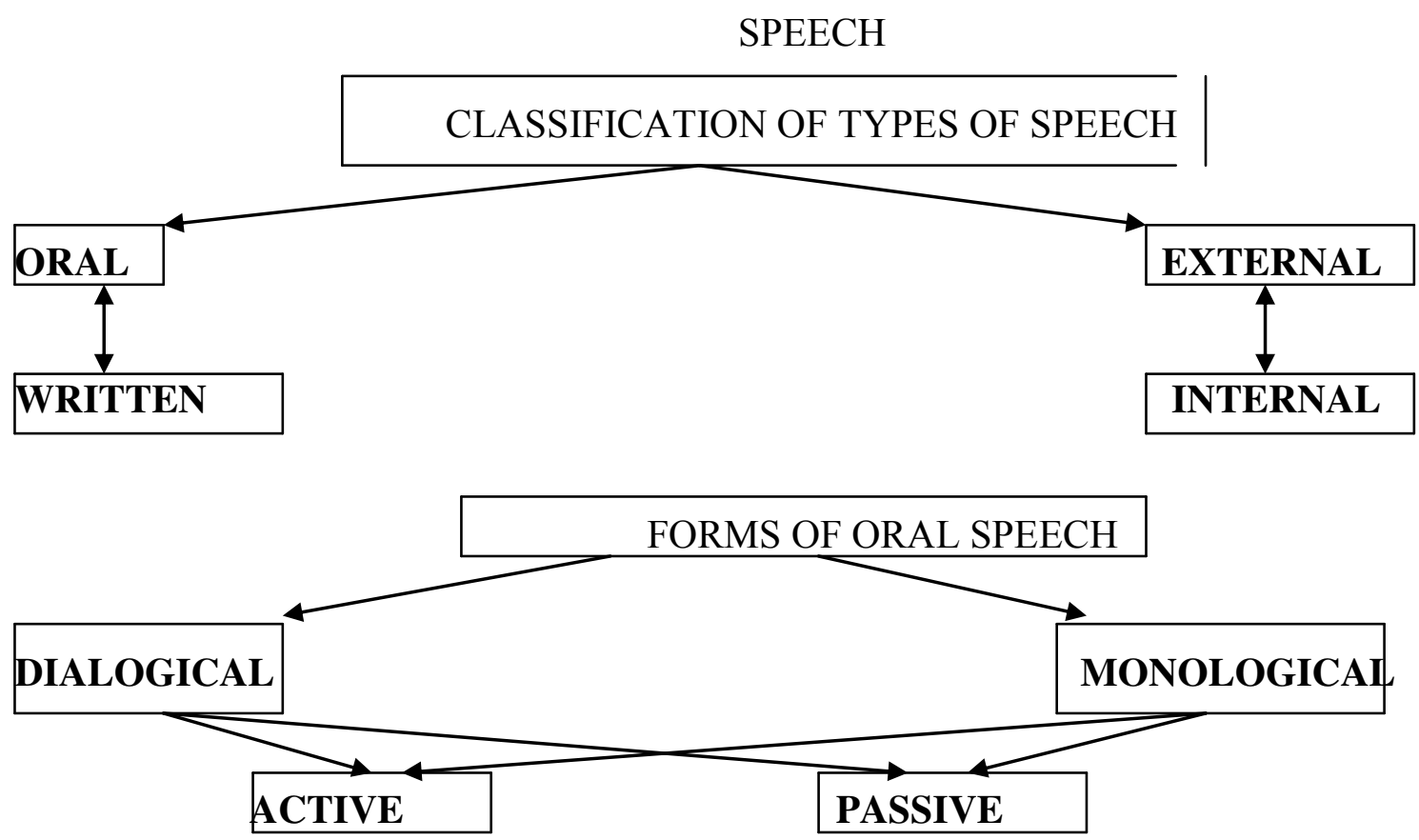

Fig. 2. Classification of types of speech

Thus, the dialogue is a process of mutual communication, when the replica changes with the answer to this replica and there is a constant change of roles. If one of the partners of communication refuses to replicate, then the dialogue turns into a monologue. If both forms refuse, then the communication stops. The linguistic behavior (Mykhalchuk \& Kryshevych, 2019) of each participant in the dialogue can be divided into some tact: one tact is speech, the other one is silent. These cycles are constantly changing each other, which suggests that dialogue to be as a rhythmic process. Moreover, the ratio of speech and silence are a stable characteristics of a man.

We distinguish two classes of dialogues: informational and interpretive ones. Informational dialogue is a form of communication, in which participants before the beginning of communication have a gap in knowledge. Interpretative dialogue is characterized by the fact that participants have approximately the same level of knowledge, but they receive a different interpretation of textual information. Thus, one of the main conditions of dialogical communication is outgoing (at least a small) gap in knowledge. That is, if the participants do not inform one another with new (unknown) information on the subject of the dialogue, and conversely students will begin to exchange wellknown truths. In this case the dialogue will not take place.

Sufficient informative dialogue is achieved not only due to the novelty of the information having been reported, but also with the help of linguistic means, which emphasize a new aspect in the perception of well-known information. But excess informativity is just as harmful to speech communication as non-informative. That is, a message with a complete description of the outside world is contrary close to a normal communication, because it is almost impossible to distinguish meaningful information from it. Therefore, the ability to duplicate information is a dominant indicator of speech culture. We should understand that low informativeness does not always indicate in practice the lack of communicative competence. This argument can be a consequence of the unwillingness of the partner to participate in a dialogue. The formal meaning of those verbal cliches, by the help of which people exchange their thoughts in public places, in transport, etc. The etiquette forms of such cliches are: "Hello!", "How is your life?", "How are you?", and they are not implied and implicated in a dialogue speech.

Another important condition for a dialogue is a great need for providing communication. It is arosen in a situation where the knowledge and the subject of communication are inadequate. The presence of a partner in this situation, which is real or potentially a source of unknown information, makes a dialogue like the emergence. Such condition as determinism is the observance of causes and effects in their direct and indirect connections. We'd conclude that when some events are 
discussed at the lessons, there must be some reasons and causes, and effects must be connected and not be arbitrary. The rupture of these links will lead to a disturbance of prognostic communication.

The next condition for prognostic communication in general and dialogical in particular is the requirement of general memory. Under this condition, those people who participate in the process communication must have at least the minimum stock of information about the past. For providing a dialogue as actualize specific characteristics of different forms of communication it is necessary at least to present a general subjective language knowledge. That is the dialogue which does not happen if the partners of communication speak different languages and if one of the partners fills the language with terminology, borrowed vocabulary or any other vocabulary that is not in the active stock of the vocabulary of another person, and in other cases there is lack of general knowledge.

Equally important for prognostic dialogue is its semantic connivance. In such a way the replies of the participants in a prognostic dialogue should have a semantic link with the topic of the dialogue, otherwise the dialogue has no meaning. Summing up everything that it was discussed in this article, it is possible to draw some conclusions about the conditions that are required for the effective prognostic dialogue. In order for such kind of a dialogue the following conditions should be available: a gap in knowledge; a need for communication; the observation of causative links; total memory; general language knowledge; semantic connectivity.

Conclusions and perspectives of further researches. So, we distinguish two levels of prognostic communication that apply to speech communication in general: the effective (informational) and business (convention). Professional development of the person takes place through qualitative changes that facilitate the emergence of a completely new level of its integrity. The latter involves qualitative changes in the characteristics of the person, the transformation personal characteristics which have already been formed, fairly consistent guidelines, values orientations, motives of behavior under the influence of constantly changing social relations. Also, the professional development of the person is carried out as a result of restructuring its orientation. At the same time, the professional orientation of the person is the result of a contradictory combination of socialization, that is emphasized on the mastery of a person with socially significant experience and culture and provide individualization (the process of the development of intelligence, will, aesthetic taste, creative abilities of the person, etc.). In the process of professional development of the person occurs the formation of the subject's integrity. This integrity consists of: 1) subordination of all elements of the structure of the personality, the subject's orientation, which ensures the continuity, the length of all periods of person's professional development; 2) to acquire the necessary professionally significant qualities, properties and characteristics.

To a large extent, significant features of the professional formation are found in the process of finding the person's individual ways of performing professional activity, which is accompanied by the formation of individual personally meaningful (including creative experience), professional self-consciousness, a system of professional motives, personal meanings, values and senses. The analysis of scientific researches, which in one way or another one deals with the problem of professional formation, shows the unity of researchers' opinions that professional formation is a dynamic process of transformation (or restructuring) personal and professional qualities, characterized by self-determination, self-improvement, self-education, self-actualization, selfrealization, actually shaping one's consciousness. Thus, professional development can be showed as a long process of mastering the profession. Thus, the analysis of the scientific literature indicates that the process of professional formation can be represented in two ways: the scheme of procedural reproduction (as a temporary sequence of stages, periods, parts) and the structure of professional activity (as a set of ways and means of performing professional activity, when their compliance is not a temporary determination, but a targeted presentation and realization). Professional formation is also understood as the development of person's professional competence, as a process of mastering the means of solving professional problems and tasks, as well as mastering models of making professionally significant decisions. These models will be built in further our researches. 


\section{REFERENCES}

Aleksandrov, A. A., Memetova, K. S., \& Stankevich, L. N. (2020). Referent's Lexical Frequency Predicts Mismatch Negativity Responses to New Words Following Semantic Training. Journal of Psycholinguistic Research, 49, 187-198. Vzyato z https://doi.org/10.1007/s10936-019-09678-3.

Arbuthnott, K., \& Frank, J. (2000). Executive control in set switching: Residual switch cost and task-set inhibition. Canadian Journal of Experimental Psychology, 54, 33-41. Vzyato z https://doi.org/10.1037/h0087328.

Booth, J. R., MacWhinney, B. \& Harasaki, Y. (2000). Developmental differences in visual and auditory processing of complex sentences. Child Development, 71 (4), 981-1003.

Crookes, G. (1989). Planning and interlanguage variation. Studies in Second Language Acquisition, 11, 367-383. Vzyato z https://doi.org/10.1017/s0272263100008391.

Dijkgraaf, A., Hartsuiker, R. J. \& Duyck, W. (2017). Predicting upcoming information in nativelanguage and non-native-language auditory word recognition. Bilingualism: Language and Cognition, 20 (5), 917-930.

Dubovyk, S. H., Mytnyk, A. Ya., Mykhalchuk, N. O., Ivashkevych, E. E., \& Hupavtseva, N. O. (2020). Preparing Future Teachers for the Development of Students' Emotional Intelligence. Journal of Intellectual Disability - Diagnosis and Treatment, 8 (3), 430-436. Vzyato $\mathrm{z}$ https://www.lifescienceglobal.com/journals/journal-of-intellectual-disability-diagnosisand-treatment/volume-8-number-3/82-abstract/jiddt/4038-abstract-preparing-futureteachers-for-the-development-of-students-emotional-intelligence.

Green, D. W. (1998). Mental control of the bilingual lexico-semantic system. Bilingualism: Language and Cognition, 1 (2), 67-81.

Mykhalchuk, N., \& Bihunova, S. (2019). The verbalization of the concept of "fear" in English and Ukrainian phraseological units. Cognitive Studies | Études cognitives, 19, 11. Warsaw. Vzyato z https://doi.org/10.11649/cs.2043.

Mykhalchuk, N. O., \& Ivashkevych, E. E. (2019). Psycholinguistic Characteristics of Secondary Predication in Determining the Construction of a Peculiar Picture of the World of a Reader. Psycholinguistics. Psykholinhvistyka. Psykholynhvystyka. Psykholohiya, 25 (1), 215231.Vzyato z https://doi.org/10.31470/2309-1797-2019-25-1-215-231.

Mykhalchuk, N., \& Khupavsheva, N. (2020). Facilitation of the Understanding of Novels by Senior Pupils as a Problem of Psycholinguistics. Psycholinguistics. Psykholinhvistyka. Psykholynhvystyka. Psykholohiya, 28 (1), 214-238. Vzyato z https://doi.org/10.31470/23091797-2020-28-1-214-238.

Mykhalchuk, H. O., \& Kryshevych, O. (2019). The peculiarities of the perception and understanding of Sonnets written by W.Shakespeare by the students of the Faculty of Foreign Languages. Psycholinguistics. Psykholinhvistyka. Psykholynhvystyka. Psykholohiya, 26 (1), 265-285. Vzyato z https://doi.org/10.31470/2309-1797-2019-26-1265-285.

Mytnyk, A., Matvienko, O., Guraliuk, A., Mykhalchuk, N., \& Ivashkevych, E. (2021). The development of constructive interaction skill as a component of social success of junior pupil. Rēzeknes Tehnologiju akadèmija. Proceedings of the International Scientific Conference, II, 387-401. Vzyato z https://doi.org/10.17770/sie2021vol2.6406.

Ернест Івашкевич

кандидат психологічних наук, старший викладач

кафедри практики англійської мови Рівненського державного гуманітарного університету, перекладач https://orcid.org/0000-0001-7219-1086

DOI https://doi.org/10.35619/praprv.v1i16.214 


\section{ПАРАДИГМА ДІАЛОГІЧНОЇ ВЗАСМОДІЇ ЯК ШЛЯХ ПРОФЕСІЙНОГО РОЗВИТКУ МАЙБУТНЬОГО ПЕРЕКЛАДАЧА}

Анотація В статті показано, щзо професійне становлення особистості відбувається иляхом якісних змін, шуо фасилітують виникнення зовсім нового рівня ї̈ иілісності. Останнє передбачає якісну зміну характеристик особистості, перетворення вже сформованих, досить сталих настановлень, иіннісних орієнтацій, мотивів поведінки під впливом постійно змінюваних суспільних відносин. Також професійний розвиток особистості здійснюється в результаті перебудови ї̈ спрямованості. Разом з изим, професійна спрямованість особистості є результатом суперечливого поєднання сочіалізачіï, тобто опанування людиною соціально значущиим досвідом і культурою, та індивідуалізації (прочесу розвитку інтелекту, волі, естетичного смаку, творчих здібностей індивіда тощо). В процесі професійного становлення особистості відбувається $і$ становлення ї̈ иілісності. Ця иілісність полягає $y:$ 1) підпорядкуванні всіх елементів структури особистості їі спрямованості, яка забезпечує безперервність, наступність та поступальність всіх періодів iї розвитку; 2) набутті необхідних професійно значущиих якостей, властивостей та характеристик. Доведено, щз великою мірою значущі особливості професійного становлення виявляються в процесі знаходження людиною індивідуальних способів виконання професійної діяльності, щзо супроводжується формуванням у індивіда особистісно значущого (в тому числі - творчого досвіду), професійної самосвідомості, системи професійних мотивів, особистісних смислів, значень $і$ иілей. Аналіз наукових публікацій, в яких так чи інакше розглядається проблема професійного становлення, свідчить про єдність думок дослідників стосовно того, щяо професійне становлення $\epsilon$ динамічним процесом перетворення (чи перебудови) особистісних і професійних якостей, який характеризується самовизначенням, самовдосконаленням, самоосвітою, самоактуалізацією, самореалізацією та власне формуванням своєї самосвідомості. Таким чином, професійне становлення можна розглядати як досить тривалий у часі процес оволодіння професією.

Отже, прочес професійного становлення може бути представленим двома способами: за схемою прочесуального відтворення (як тимчасова послідовність ступенів, періодів, стадій) $i$ за структурою професійної діяльності (як сукупність способів $i$ засобів виконання професійної діяльності, коли їхнє дотримання має не тимчасову, а иільову детермінацію). Під професійним становленням ми розуміємо формування професійной компетентності як процес оволодіння засобами розв'язання професійних задач та завдань, а також опанування моделями прийняття професійно значущих рішень. Виокремлено основні стадіі професійного становлення фахівия: підготовча (довузівська) стадія, пов'язана суто з вибором професії; початкова (вузівська) стадія, під час якої формуються професійно важливі уміння, характеристики та властивості особистості; основна (післявузівська) стадія як період розвитку особистісних якостей людини, щзо фасилітують ї повну самореалізацію в професійній діяльності. Саме на цььому етапі відбувається становлення особистості професіонала. Зазначено, що професійне становлення особистості є иілісним процесом, який динамічно розгортається в часі та просторі, триває від формування професійних намірів до повної реалізації себе у творчій професійній діяльності, основною суперечністю якої є протиріччя між сформованими властивостями особистості і об'єктивними вимогами провідної діяльності, значення якої полягає в тому, що вона має зумовлювати подальший особистісний розвиток. Реалізуючи себе в провідній діяльності, особистість поступово змінюється, щуо призводить до перебудови мотивів своєї провідної діяльності, до формування нових властивостей, якостей та характеристик людини, які є надзвичайно важслиими та значущими для здійснення професійної діяльності.

Ключові слова: діалогічна взаємодія, професійний розвиток, творча професійна діяльність, професійні наміри, професійна компетентність, творчий досвід. 